\title{
Post-translational regulation of endothelial nitric oxide synthase in vascular endothelium
}

\author{
Jin Qian ${ }^{1 *}$ and David Fulton ${ }^{2}$ \\ 1 Pulmonary and Critical Care, School of Medicine, Stanford UniversityNA Palo Alto Health Care System, Palo Alto, CA, USA \\ 2 Vascular Biology Center, Georgia Regents University, Augusta, GA, USA
}

\author{
Edited by: \\ Shruti Sharma, Georgia Regents \\ University, USA \\ Reviewed by: \\ R. Dan Rudic, Medical College of \\ Georgia, USA \\ Anuran Chatterjee, University of \\ California San Francisco, USA \\ *Correspondence: \\ Jin Qian, Pulmonary and Critical \\ Care, School of Medicine, Stanford \\ UniversityNA Palo Alto Health Care \\ System, 3801 Miranda Ave., Bldg. \\ 101, Rm. B4-105, Mail Code 1540, \\ Palo Alto, CA, 94304 USA \\ e-mail: jinq@stanford.edu
}

Nitric oxide (NO) is a short-lived gaseous signaling molecule. In blood vessels, it is synthesized in a dynamic fashion by endothelial nitric oxide synthase (eNOS) and influences vascular function via two distinct mechanisms, the activation of soluble guanylyl cyclase (sGC)/cyclic guanosine monophosphate (cGMP)-dependent signaling and the S-nitrosylation of proteins with reactive thiols (S-nitrosylation). The regulation of eNOS activity and NO bioavailability is critical to maintain blood vessel function. The activity of eNOS and ability to generate NO is regulated at the transcriptional, posttranscriptional, and posttranslational levels. Post-translational modifications acutely impact eNOS activity and dysregulation of these mechanisms compromise eNOS activity and foster the development of cardiovascular diseases (CVDs). This review will intergrate past and current literature on the post-translational modifications of eNOS in both health and disease.

Keywords: eNOS, nitric oxide, post-translational, vessel, vascular diseases
Cardiovascular disease (CVD) remains the primary cause of death in developed and developing countries, and almost 800,000 people die annually in the US from CVDs that include atherosclerosis, hypertension, congestive heart failure, and stroke (Heron et al., 2009). The endothelium is a single layer of cells lining the lumen of all blood vessels. Endothelial cells provide a barrier to thrombosis, regulate both acute, and chronic blood flow, local inflammation, and vascular cell proliferation (Cines et al., 1998). Loss of endothelial function precedes vascular disease and is thought to be an initiating event (Jensovsky, 1994). Nitric oxide (NO) is a major mediator of endothelial function and is synthesized in endothelial cells by endothelial nitric oxide synthase (eNOS). eNOS-derived NO plays a vital role in maintaining cardiovascular homeostasis by influencing vascular tone, smooth muscle cell proliferation, and migration, leukocyte adhesion, and platelet aggregation (Forstermann and Munzel, 2006). Numerous studies have shown that eNOS is protective against pathologic vascular remodeling, hypertension and atherosclerosis (Shesely et al., 1996; Rudic et al., 1998; Kuhlencordt et al., 2001). Moreover, reduced expression and dysregulation of eNOS which result in the decreased bioaviability of $\mathrm{NO}$ and the increased production of superoxide instead of $\mathrm{NO}$, increases the severity of CVD (Oemar et al., 1998; Ozaki et al., 2002). Therefore, corruption of eNOS/NO signaling is considered an early and common mechanism underling numerous vascular pathologies. A greater understanding of eNOS regulation and new approaches to improving eNOS function is a vital goal in the improved treatment of CVDs.

\section{NO}

In 1980, an endothelium-derived relaxing factor (EDRF) was discovered in rabbit aortae by Furchgott and Zawadzki (1980). Breakthrough studies by several groups later identified EDRF as
NO (Katsuki and Murad, 1977; Ignarro et al., 1987; Palmer et al., 1987). NO is a highly lipophilic, hyper reactive, diffusible free radical gas (Dudzinski et al., 2006) with a short half-life in biological fluids (Thomas et al., 2001). NO is produced in vary degrees in the cardiovascular, nervous, digestive and immunological systems where it exerts a variety of biological actions under both physiological and pathological conditions (Bian et al., 2008). The paired oxygen and nitrogen atoms of $\mathrm{NO}$ exhibit characteristics of both a partial double bond and partial triple bond as a result of an unpaired electron (Dudzinski et al., 2006). The free radical character of $\mathrm{NO}$ confers unique reactivities and is responsible for the interaction of $\mathrm{NO}$ with numerous cellular and extracellular targets. As a lipophilic gas, NO readily diffuses away from the site of synthesis, across multiple cellular membranes to alter signaling in distal cells (Dudzinski et al., 2006). Well-characterized actions of NO include the stimulation of vasodilation, inhibition of smooth muscle cell proliferation, leukocyte adhesion, and platelet aggregation (Forstermann and Munzel, 2006). Impaired NO activity is commonly observed as a critical event in the pathogenesis of CVD (Verhaar et al., 2004; Dudzinski et al., 2006; Versari et al., 2009). As a consequence, a major therapeutic goal in improving endothelial function in CVD is centered around enhancing deficient NO-signaling (Verhaar et al., 2004).

\section{NOS}

The NOS family of enzymes consists of three distinct isoforms: neuronal (nNOS, alternatively designated NOSI as it was the first NOS isoform to be discovered), inducible (iNOS or NOSII), and endothelial (eNOS or NOSIII) NOS. All three isoforms are expressed in the human cardiovascular system (Balligand et al., 1994; Shen et al., 1999; Sears et al., 2003). The neuronal isoform, nNOS has been shown to be expressed in vascular smooth muscle 
of certain types of blood vessels (Forstermann and Sessa, 2012). The inducible, iNOS is not normally present in blood vessels but can be induced following infection or cytokine stimulation and is prominently found in vascular smooth muscle and immune cells (Kroncke et al., 1998; Kibbe et al., 1999). In contrast, eNOS is prominently expressed in all endothelial cells (Toda, 2012). Expression of eNOS was originally thought to be constitutive, but recent studies have shown that its expression levels fluctuate in response to mechanical stimulation (Ziegler et al., 1998), growth factor (Ziegler et al., 1998; Bouloumie et al., 1999), and cytokines (Gomez-Fernandez et al., 2005).

eNOS is a bi-domain enzyme comprising a C-terminal reductase domain which binds nicotinamide adenine dinucleotide phosphate (NADPH), the flavins mononucleotide (FMN), and flavin adenine dinucleotide (FAD); an N-terminal oxidase domain which binds heme, zinc, tetrahydrobiopterin $(\mathrm{BH} 4)$, and calmodulin. In addition to the bi-domain catalytic structure, eNOS forms homodimers and dimerization is essential for enzymatic activity (Panda et al., 2002). Electrons flow from the C-terminal reductase domain of one NOS monomer to the N-terminal oxygenase domain of the other NOS monomer (Siddhanta et al., 1998). The primary mode of enzyme activation is the binding of calcium-bound calmodulin to the $\mathrm{N}$ terminal CaM-binding domain. This facilitates a structure change and the flow of electrons from NADPH through the flavins to the oxygenase domain of the other eNOS monomer (Abu-Soud et al., 1994). Within the oxygenase domain, molecular oxygen is bound to heme and reduced and then incorporated into Larginine to form NO and L-citrulline (Fleming and Busse, 1999; Verhaar et al., 2004). To generate NO, 1 mole of l-arginine, 1.5 moles of NADPH, and 2 moles of molecular oxygen are required (Dudzinski et al., 2006). To efficiently produce NO, eNOS must effectively coordinate the binding of multiple substrates and cofactors. Dirsuption of this highly coordinated catalysis, such as which occurs in the absence of adequate substrate concentrations or other modifications can result in the production of superoxide and peroxynitrite (Dudzinski et al., 2006).

\section{FUNCTIONAL MECHAMISMS OF NO}

In blood vessels, NO signaling is orchestrated via at least two distinct mechanisms. The first is the well characterized activation of the high affinity soluble guanylyl cyclase (sGC)-cyclic guanosine monophosphate (cGMP) signaling pathway (Ziche et al., 1993; Dimmeler et al., 1997; Ziche and Morbidelli, 2000; Friebe and Koesling, 2003) This pathway has been established to mediate the NO-dependent relaxation of vascular smooth muscle and the ability of $\mathrm{NO}$ to suppress platelet aggregation (Friebe et al., 2007). NO-sensitive soluble guanylyl cyclase (sGC) is the cognate receptor for $\mathrm{NO}$ and once activated, sGC catalyzes the formation of the intracellular messenger cGMP. The affinity of sGC for NO is very high and thus low amounts of NO (nM) activate this pathway (Beckman and Koppenol, 1996). Binding of NO, to the reduced heme moiety of sGC increases the conversion of guanosine triphosphate (GTP) to cGMP, which in turn activates downstream effector systems such as protein kinases, phosphodiesterases, and ion channels (Murad, 1986). Dysfunction of this pathway has been reported to contribute to the pathogenesis of many disorders, including hypertension and atherosclerosis (Ruetten et al., 1999; Mizuno et al., 2010). Genetic deletion of sGC results in reduced endothelial-dependent relaxation, reduced ability of NO to relax smooth muscle and prevent platelet activation and hypertension (Buys et al., 2008; Dangel et al., 2010; Groneberg et al., 2010).

However, not all actions of NO are dependent on activation of sGC and cGMP/PKG signaling. A second mechanism is called S-nitrosylation and involves the ability of $\mathrm{NO}$ or its metabolites to react with cysteine residues of target proteins (Stamler et al., 2001; Dudzinski et al., 2006). In the past decade, reversible redox modifications of cysteine residues have garnered considerable attention as a mechanism of intracellular signaling. S-nitrosylation is increasingly recognized for its ability to influence protein function in a reversible manner analogous to phosphorylation (Stamler et al., 2001). Indeed, like phosphorylation, a motif for S-nitrosylation has been postulated that consists of a cysteine residue located between an acidic and a basic amino acid that together lie within a hydrophobic environment (Yeh et al., 1999; Hess et al., 2001, 2005; Zimmet and Hare, 2006; Foster et al., 2009a; Xue et al., 2010). The reversal of S-nitrosylation has been shown to be mediated by two major enzymes, the S-nitrosoglutathione reductase (GSNOR) (Liu et al., 2001, 2004) and thioredoxin 1 (Trx1) (Mitchell and Marletta, 2005). S-nitrosylation has been shown to impact a wide range of biological processes including apoptosis (Dimmeler et al., 1997; Kang-Decker et al., 2007; Benhar et al., 2008; Cho et al., 2009), cellular trafficking (Ozawa et al., 2008), proliferation (Ignarro et al., 2001), NO synthase activity (Erwin et al., 2005), ion channel activity and muscle contractility (Xu et al., 1998), transcription factor activity (Palmer et al., 2000), protein secretion (Matsushita et al., 2003), blood flow (Singel and Stamler, 2005), as well as a wide range of pathophysiological conditions (Foster et al., 2009b). The dysregulation of protein S-nitrosylation has been observed in a wide spectrum of human diseases, and is increasingly recognized as source of aberrant cellular function (Lim et al., 2008; Cho et al., 2009; Lima et al., 2010; Wei et al., 2010; Seth and Stamler, 2011). In contrast to sGC signaling, higher amounts of NO $(\mu \mathrm{M})$ are required for nitrosylation and because of the high diffusion co-efficient of NO (Martinez-Ruiz and Lamas, 2005), this may allow for the selective nitrosylation of proteins within close proximity to the source of NO. To date, a large number of SNO-proteins have been identified, but the observed specificity of S-nitrosylation in terms of target proteins and specific cysteines within modified proteins is not yet well understood (Seth and Stamler, 2011).

\section{POST-TRANSLATIONAL REGULATION OF ENOS}

eNOS activity and ultimately the amount of NO synthesized is controlled by a complex integration of transcriptional, posttranscriptional and post-translational mechanisms (Dudzinski et al., 2006). Acutely, eNOS activity can be robustly regulated by a number of post-translational modifications, including fatty acid acylation, substrate, and co-factor availability, degree of phosphorylation, S-nitrosylation, acetylation, and protein-protein interactions. 


\section{INTRACELLULAR LOCALIZATION}

Within endothelial cells, eNOS has been shown to be concentrated within plasma membrane (PM) caveolae, a pocket-like invagination on the membrane, which is enriched in cholesterol and sphingolipids and is important for signal transduction (Lisanti et al., 1994). Not surprisingly, it has been shown that caveolae are important for eNOS function (Shaul et al., 1996; Sowa et al., 2001). The extraction of membrane cholesterol and exposure of endothelial cells to oxidized low density lipoprotein (LDL) all have been shown to reduce eNOS activity by displacing eNOS from the PM to intracellular sites (Blair et al., 1999; Nuszkowski et al., 2001) suggesting that eNOS targeting to cholesterol enriched domains is important for NO synthesis. The subcellular location of eNOS is mediated by protein fatty acid acylation. There are two major lipid modifications: the co-translational $\mathrm{N}$-myristoylation on glycine2 and post-translational palmitoylation on cysteines-15 and 26. Myristoylation is the first and necessary step for subsequent palmitoylation (Liu and Sessa, 1994; Robinson and Michel, 1995). Once eNOS is myristoylated and palmitoylated, it is subsequently targeted to the Golgi complex and plasmalemmal caveolae (Liu and Sessa, 1994; Liu et al., 1995, 1997; Garcia-Cardena et al., 1996b). Previous studies have shown that a glycine-2 to alanine (G2A) mutant of eNOS is neither myristoylated nor palmitoylated and can be found in the cytosol instead of bound to peripheral membranes. The G2A eNOS retains equivalent catalytic activity in assays replete with cofactors, but within cells, it produces less NO than the wild type eNOS. These studies revealed an important role of intracellular location in the catalytic regulation of eNOS (Church and Fulton, 2006). The importance of palmitoylation for optimal eNOS function was revealed by mutation of Cys-15 and Cys-26 to serines, which prevents eNOS palmitoylation. Loss of palmitoylation leads to the intracellular redistribution of eNOS and diminishes NO synthesis in cells (Liu et al., 1995; Robinson and Michel, 1995). Further analysis of eNOS targeting motifs revealed that the first 35 amino acids including the $\mathrm{N}$-myristoylation and palmitoylation sites are sufficient to provide intracellular targeting of eNOS to regions of the Golgi and PM (Liu et al., 1997). In addition to the PM, eNOS can be found attached to various intracellular membranes, such as Golgi, which produce considerably less NO than PM eNOS. Functional relevance of eNOS on the Golgi remains to be further established (Liu et al., 1997). The appropriate intracellular localization and distribution of eNOS in PM and Golgi apparatus is necessary for Akt (and agonist)-dependent eNOS phosphorylation on Ser-1179 and is impaired in the cytosolic G2A eNOS (Fulton et al., 2002). In COS-7 cells, when reconstituted with a PM localized eNOS, eNOS is highly phosphorylated and highly active in response to the elevation of intracellular calcium. In contrast, Golgi eNOS is less phosphorylated under basal conditions, but preferentially activated via mechanisms involving Akt-dependent phosphorylation (Fulton et al., 2004). It has also been demonstrated that eNOS and caveolin-1 can translocate into the nucleus following vascular endothelial growth factor (VEGF) stimulation (Feng et al., 1999). The presence of eNOS in mitochondria has also been shown and termed as "mitochondria NOS" (mtNOS), which is thought to contribute to superoxide production in endothelial cells (Brodsky et al., 2002). C-terminal polybasic domains with an autoinhibitiory domain of eNOS have also been shown to influence membrane binding and mitochondrial localization (Gao et al., 2004). However, the targeting of eNOS to the nucleus or mitochondria results in an enzyme that produces very little NO (Jagnandan et al., 2005). Targeting calcium-independent forms of NOS (iNOS) or a novel calcium-insensitive eNOS to the cytosol or to the nucleus and mitochondria resulted in activity equal to that targeted to the membranes of the Golgi and PM suggesting that calcium or mechanisms regulating calciumsensitivity are central to location-dependent changes in eNOS activity (Jagnandan et al., 2005; Church and Fulton, 2006).

Although location is clearly an important factor for regulating eNOS activity, much less is known about its contribution to downstream NO-dependent signal transduction. Recent studies have found that eNOS in the Golgi can influence the Snitrosylation of local proteins (Iwakiri et al., 2006; Sangwung et al., 2012). When expressed in the endothelium of intact blood vessels, the PM location of eNOS results in a greater ability to elicit cGMP-dependent signaling and endothelium-dependent relaxation vs. a Golgi-targed enzyme (Qian et al., 2010). The ability of PM eNOS to elicit more pronounced endothelium-dependent relaxations and greater increases in cGMP accumulation is not surprising given the extraordinary sensitivity of sGC for $\mathrm{NO}$ (Russwurm et al., 1998) and most likely reflects the increased NO production from this location (Fulton et al., 2004). Consistent with these studies, the S-nitrosylation-dependent inhibition of Von Willebrand factor (vWF) release from endothelial cell is greater in endothelial cells expressing eNOS at the PM compared to the Golgi. Mechanistically, it was shown that the amount of NO, and not the location of synthesis, is the most important variable influencing protein S-nitrosylation and vWF suppression (Qian et al., 2010). The importance of higher concentrations of $\mathrm{NO}$ are also observed in the ability of either PM or Golgi-restructed eNOS to influence inflammatory NF- $\kappa \mathrm{B}$ signaling (Qian and Fulton, 2012). While a PM location favors the highest output of NO from eNOS, it is also the most susceptible to extracellular influences such as oxidized LDL which selectively reduces NO release from PM-targeted eNOS (Shaul, 2002; Zhang et al., 2006). eNOS restricted to the Golgi is resistant to the actions of oxidized LDL and Golgi restricted eNOS is also capable of supplying biologically active NO to adjacent smooth muscle cells and mediating endothelium-dependent relaxation. While eNOS is generally regarded as being protective in murine models of atherosclerosis (Kuhlencordt et al., 2001), it is not yet known whether a Golgi location of eNOS would offer more protection against lesion formation vs. the PM.

\section{ENOS PHOSPHORYLATION}

eNOS is dynamically regulated by changes in protein phosphorylation. It is known that eNOS can be phosphorylated at multiple sites, including serine $(\mathrm{S})$, threonine $(\mathrm{T})$, and tyrosine (Y) residues (Michel et al., 1993; Corson et al., 1996; GarciaCardena et al., 1996a; Fulton et al., 2005). Seven primary sites of eNOS phosphorylation have been identified in human isoform on Y81, S114, T495, S615, S633, Y657, and S1177 (equivalent to Y83, S116, T497, S617, S635, Y659, and S1179 of bovine eNOS 
due to two extra amino acids in the bovine eNOS sequence) (Venema, 2002; Fulton et al., 2005; Fisslthaler et al., 2008). Folic acid incubation can modulate eNOS phosphorylation at multiple sites without change eNOS expression level (Taylor et al., 2013).

The phosphorylation of human eNOS S1179 on the Cterminal reductase domain was one of the first eNOS phosphorylation sites identified and is a positive regulator of eNOS activity (Fulton et al., 1999; Scotland et al., 2002). Phosphorylation of S1179 via Akt has been shown to be important in the activation of eNOS in endothelial cells in response to VEGF and shear stress (Dimmeler et al., 1999; Fulton et al., 1999; Gallis et al., 1999; Michell et al., 1999). Other protein kinases have also been shown to phosphorylate eNOS at S1179, including adenosine monophosphate-activated kinase (AMPK) (Chen et al., 1999), CaM protein kinase II (Fleming et al., 2001), protein kinase A (PKA) (Butt et al., 2000; Gangopahyay et al., 2011), and protein kinase G (PKG) (Butt et al., 2000). Enzymatically, the phosphorylation of $\mathrm{S} 1179$ increases electron flow and calcium-calmodulin sensitivity (McCabe et al., 2000) which collectively increase NO synthesis at lower levels of intracellular calcium.

The phosphorylation of both S617 and S635 have also been shown to promote increased eNOS-derived NO release (Michell et al., 2002). The phosphorylaiton of S617 can be induced by PKA or Akt activity, and may serve to sensitize eNOS to calmodulin binding and modulate the phosphorylation of other eNOS sites (Michell et al., 2002; Bauer et al., 2003; Erwin et al., 2005). Mimicking the phosphorylation by mutating S617D only increases the $\mathrm{Ca}^{2+} / \mathrm{CaM}$ sensitivity without affecting overall enzyme activity (Michell et al., 2002). S635, in the FMN binding domain, is phosphorylated by PKA (Michell et al., 2002) and may represent a second stimulatory phosphorylation response (Boo et al., 2002). Mimicking phosphorylation with the S635D mutation results in enhanced eNOS overall activity as well as increased sensitivity to $\mathrm{Ca}^{2+} / \mathrm{CaM}$. Both $\mathrm{S} 617$ and $\mathrm{S} 635$ are present on the same auto-inhibitory domain on eNOS. Deletion of this domain along with the other autoinhibitory domain containing S1179 results in an eNOS enzyme that is calcium-insensitive, which strongly support the ability of phosphorylation to modulate eNOS-calcium sensitivity (Church and Fulton, 2006).

The phosphorylation of T497 inhibits eNOS catalytic activity and is thought to interfere with the binding of calcium-activated calmodulin (Fleming et al., 2001). The phosphorylation of T497 is mediated by AMPK (Chen et al., 1999) and protein kinase C (PKC) (Chen et al., 1999; Fleming et al., 2001; Michell et al., 2001). Importantly, agonists such as bradykinin which increase NO release, simultaneously induce the dephosphorylation of T497 (Fleming et al., 2001; Harris et al., 2001), which enables calmodulin binding and eNOS activation. Dephosphorlyation of T497 is mediated by calcineurin and inhibited by cyclosporine A (Harris et al., 2001).

S116 was first identified as a phosphorylation site that can be induced by shear stress (Gallis et al., 1999). The impact of phosphorylation on S116 in the eNOS oxygenase domain remains controversial (Mount et al., 2007). S116 was previously suggested to be a negative regulatory site (Bauer et al., 2003). Evidence to support this derives from the ability of VEGF to induce the dephosphorylation of S116 and a phospho null mutation, S116A has increased activity (Kou et al., 2002). In contrast, mimicking the phosphorylation of eNOS by S116D mutation decreases basal NO release from endothelial cells and impairs endotheliumdependent relaxation in aortic rings (Li et al., 2007). The mechanism by which $\mathrm{S} 116$ phosphorylation impacts eNOS activity is not yet fully understood but may involve increased binding to the negative regulator, caveolin-1 [105]. Dephosphorylation is mediated by calcineurin which promotes increased activity via c-Src binding and phosphorylation of tyrosine 83 (Ruan et al., 2013). In contrast, shear stress (Gallis et al., 1999) and high density lipoprotein (HDL) (Drew et al., 2004) which increase eNOS activity have also been reported to increase S116 phosphorylation. Other studies have found no change in Ser116 phosphorylation with either shear stress or VEGF, which may reflect cell specific differences or greater methodological difficulty in detecting the phosphorylation of this site (Boo et al., 2002).

Y83 is a recently identified eNOS phosphorylation site (Fulton et al., 2005, 2008). Phosphorylation of this residue is mediated by Src kinase in response to different eNOS-activating agonists, which increases eNOS activity and NO production in both cotransfected COS-7 cells and in endothelial cells (Venema, 2002; Fulton et al., 2005). Phosphonull Y83F mutants of eNOS produce less NO and exhibit impaired endothelium-dependent relaxation when reconstituted in aorta from eNOS knockout mice. The tyrosine phosphorylation of eNOS has also been reported on Y659 by proline-rich tyrosine kinase 2 (PYK2). Phosphorylation of this site impairs eNOS activity (Loot et al., 2009).

\section{PROTEIN-PROTEIN INTERACTION}

Calmodulin (CaM) was the first protein identified to directly bind and regulate the activity of eNOS. CaM binds to a cognate binding site on eNOS that lies between the oxygenase and reductase domains. Binding displaces an adjacent autoinhibitory loop and promotes NADPH-dependent electron flux to the heme moiety (Fulton et al., 2001). Electron transfer is impeded in the absence of bound calmodulin, thus eNOS catalytic activity is suppressed. eNOS activity is proportional to the level of intracellular calcium and the binding of calcium-activated calmodulin. The intracellular location of eNOS can influence its ability to respond to calcium, with eNOS at the PM being more responsive than intracellular sites particularly in unstimulated cells (Church and Fulton, 2006). This may be due to proximity to ion channels or transporters that are present in the PM. Prolonged cell stimulation and calmodulin binding may trigger the depalmitoylation of eNOS via Acyl-Protein Thioesterase-1 (APT-1) and membrane translocation (Michel et al., 1997; Yeh et al., 1999). While $\mathrm{Ca}^{2+} / \mathrm{CaM}$ is the primary means of activating eNOS in vitro, it is not the only game in town and this is revealed by changes in calcium-sensitivity and an ability to generate NO with resting levels of calcium. Many other factors can contribute to the $\mathrm{Ca}^{2+} / \mathrm{CaM}$ sensitivity of eNOS. For example, acylation, acetylation, phosphorylation, caveolin-1 and heat shock protein 90 (hsp90) binding can also influence the CaM-dependent activation of eNOS (McCabe et al., 2000; Fulton et al., 2001; Sessa, 2004).

Caveolin-1 (Cav-1) has been shown to directly bind to eNOS. The scaffolding domain of Cav-1 interacts with the caveolin binding motif on eNOS that is located between amino acids 350-358. 
The binding of Cav-1 inhibits eNOS activity and reduces NO production (Smart et al., 1999). Cav-1 binding is inhibited by calcium-mobilizing agonists and the elevation of intracellular calcium. Binding of calcium-activated calmodulin to eNOS displaces Cav-1 and facilitates eNOS activation (Govers et al., 2002; Fleming and Busse, 2003). Association of eNOS with Cav-1 can be decreased in a dose dependent manner by folic acid treatment (Taylor et al., 2013). Over-expression of Cav-1 in COS-7 cells suppresses NOS activity (Garcia-Cardena et al., 1997; Michel et al., 1997) and peptides encompassing the caveolin-1 scaffolding domain inhibit NO release from eNOS (Bucci et al., 2000). In $\mathrm{Cav}-1^{-/-}$mice, both basal and stimulated eNOS activity and vasorelaxation are enhanced in blood vessels (Drab et al., 2001; Razani et al., 2001). In addition, peptides that displace Cav-1 from eNOS, enhance the synthesis of NO and promote vasodilation and further validate the inhibitory role of caveolin-1 in eNOS-dependent NO release (Bernatchez et al., 2011).

The hsp90s comprise a family of molecular chaperones responsible for the proper folding and maturation of client proteins (Pratt, 1997). As part of their chaperone activities, hsp90 regulates a variety of signal transduction pathways. Hsp90 has been shown to interact with eNOS under resting conditions and binding to eNOS is increased with numerous endothelial cell stimuli including VEGF, histamine, fluid shear stress, and estrogen, which promotes increased eNOS activity and NO release (Venema et al., 1996; Garcia-Cardena et al., 1998; Russell et al., 2000). There are multiple mechanisms by which hsp90 influences eNOS. Hsp90 binding to eNOS induces a conformational change in eNOS that promotes increased activity and increased enzymatic fidelity (Pritchard et al., 2001; Ou et al., 2003, 2004). Hsp90 binds to the oxygenase domain of eNOS between amino acid 310-323 (Xu et al., 2007) and it likely thus influences the binding/function of heme as has been shown for other heme containing proteins (Billecke et al., 2004; Ghosh and Stuehr, 2012). In addition, hsp90 can also function as a scaffold or platform for the recruitment and regulation of other regulatory proteins including kinases and phosphatases that can then secondarily influence eNOS function (Fulton et al., 2001). Geldanamycin (GA) can disrupt hsp90-eNOS binding and prevent Akt recruitment to eNOS to reduce eNOS activity (Roviezzo et al., 2007). Co-Immunopercipitaion revealed that interaction of hsp90 and eNOS was increased by folic acid (Taylor et al., 2013).

eNOS localization and activity can also be regulated by protein:protein interaction. Nitric oxide synthase interacting protein (NOSIP) and nitric oxide synthase traffick inducer (NOSTRIN) are both eNOS associated proteins. NOSIP and NOSTRIN, promote the translocation of eNOS from plasmalemmal caveolae to other intracellular compartments, such as Golgi. By promoting a reduced proportion of eNOS at the PM portion, NOSIP and NOSTRIN decrease eNOS activity and NO release (Dedio et al., 2001; Zimmermann et al., 2002).

Several transmembrane receptors and ion channels have also been shown to impact eNOS regulation. The bradykinin (BK) B2 receptor is a G-protein coupled receptor (GPCR) also functions as an allosteric regulator of eNOS activity. The binding of eNOS and the BK B2 receptor is dynamic and driven by $\mathrm{Ca}^{2+} / \mathrm{CaM}$ secondarily to cell stimulation with $\mathrm{BK}$ or other calcium mobilizing agonists and are reversed by blocking the elevation in intracellular calcium (Fulton et al., 2001). Using Coimmunoprecipitation experiments followed by mass spectrometry, the voltage dependent anion channel-porin was identified as a direct binding partner of eNOS and interaction with eNOS augmented activity probably through increased intracellular calcium (Sun and Liao, 2002).

Recently, another novel form of eNOS regulation was revealed, through phosphorylation mediated-protein association. The interaction of Pin 1 prolyl isomerase with eNOS was observed only when S116 is phosphorylated. In both endothelial cells and blood vessels, inhibition of Pin 1 increased NO release, and overexpression of Pin 1 supressesed NO production, validating the functional significance of this interaction (Ruan et al., 2011).

eNOS function can also be indirectly regulated by many other proteins. APT-1 induces the depalmitoylation and translocation of eNOS (Yeh et al., 1999; Prabhakar et al., 2000). The cationic amino acid transporter-1 (CAT-1) is a major L-arginine transporter in ECs and has been shown to interact directly with eNOS and enhance its activity through a mechanism that paradoxically does not involve L-arginine transport (Li et al., 2005). In addition to CAT-1, the arginine recycling enzymes argininosuccinate lyase (ASL), and argininosuccinate synthase (ASS) have been shown to bind and regulate eNOS activity, but surprisingly this also does not require catalytic activity (Chen et al., 2013). The cell division cycle 37 (Cdc 37), a co-chaperone of hsp90 interacts directly with eNOS and inhibits its activity (Harris et al., 2006). The C-terminal hsp70-interacting protein (CHIP) associates with both hsp70 and 90 , and negatively regulates eNOS trafficking into the Golgi complex (Jiang et al., 2003). Dynamin-2, a large GTPase has also been shown to bind to eNOS. Binding to eNOS can be increased by calcium ionophore and augments eNOS activity (Cao et al., 2001). Beta-actin, generally acknowledged for its house keeping functions, is associated with the eNOS oxygenase domain and that binding activates eNOS to increase NO production and decrease superoxide formation (Kondrikov et al., 2010). Another novel eNOS partner is the G-protein-coupled receptor kinase interactor-1 (GIT1) shown to bind eNOS in sinusoidal endothelial cells. Association of GIT1 with eNOS promoted Ser1179 phosphorylation, enzyme activation, and NO synthesis (Liu et al., 2012). In addition, eNOS has also been shown to interact with signaling molecules including Src kinase (Fulton et al., 2005), Akt-kinase (Michell et al., 1999), and sGC (Venema et al., 2003). Given the large array of eNOS interacting proteins an important unresolved question is how binding is coordinated and whether binding is direct or indirect. For example, hsp90 binds numerous co-chaperones and hundreds of client proteins and could readily mediate indirect associations of multiple proteins. Some binding partners are bound constitutively and other dynamic. The best described dynamic partner is calmodulin which may actually be bound constitutively and alternate between low and high affinity binding. How the other eNOS binding proteins are shuttled on and off is less well described.

\section{SUBSTRATE AND COFACTOR AVAILABILITY}

$\mathrm{L}$-arginine is the substrate for eNOS and the catalytic activity also requires NADPH and the co-factor, tetrahydrobiopterin 
(BH4). Many studies have suggested that cellular deficiency of either L-arginine or $\mathrm{BH} 4$ can cause endothelial dysfunction by "uncoupling" eNOS. Uncoupled eNOS is a term used to describe a change in the ratio of $\mathrm{NO}$ to $\mathrm{O}_{2}^{-}$produced in favor of decreased $\mathrm{NO}$ and increased $\mathrm{O}_{2}^{-}$. The consequences of this are both reduced synthesis and bioavailability of $\mathrm{NO}$ and increased levels of superoxide and peroxynitrite (Forstermann and Munzel, 2006). Depletion of the NOS substrate L-arginine has been proposed to occur via catabolism by arginase. Both arginase I and II in endothelial cells have also been proposed to inhibit eNOS activity via this mechanism (Wu and Morris, 1998; Zhang et al., 2001; Hallemeesch et al., 2002; Berkowitz et al., 2003). Increased Arginase II levels co-presents with endothelial dysfunction and has been observed with CVDs such as atherosclerosis (Ming et al., 2004) or hypertension (Zhang et al., 2004). Not surprisingly, the supplementation of L-arginine has been shown to have beneficial effects on eNOS activity (Elms et al., 2013) and in humans with pathophysiological conditions including hypercholesterolemia and hypertension. However, this remains a controversial approach as the levels of L-arginine, even in disease states, are much higher than required for eNOS synthesis (Drexler et al., 1991; Rossitch et al., 1991; Imaizumi et al., 1992) and more importantly long term supplementation of L-arginine may be detrimental (Chen et al., 2013).

Oxidation and depletion of BH4 levels promotes eNOS (Vasquez-Vivar et al., 1998) and endothelial dysfunction (Shinozaki et al., 1999; Hong et al., 2001). Supplementation of BH4 has been shown to improve endothelial-dependent vasodilation in animal models of diabetes (Pieper and Siebeneich, 1997) and insulin resistance (Shinozaki et al., 2000), as well as in patients with hypercholesterolemia (Stroes et al., 1997), diabetes mellitus (Pieper, 1997), essential hypertension (Higashi et al., 2002), and in chronic smokers (Heitzer et al., 2000). These findings suggest that limited synthesis or recycling of $\mathrm{BH} 4$ is an important rate-limiting step in the eNOS-dependent synthesis of NO in CVD states.

\section{S-NITROSYLATION}

Not only is eNOS activity influenced by a wide range of protein regulators, but eNOS is itself post-translationally modified by Snitrosylation in a product feedback relationship that constrains further NO synthesis. S-nitrosylation is a covalent modification of protein cysteine thiols by NO to yield an S-nitrosothiol (SNO) (Erwin et al., 2005; Lima et al., 2010). In endothelial cells, the source of NO for nitrosylation comes primarily from eNOS. The subcellular targeting of eNOS to the PM has been shown to be important for eNOS S-nitrosylation which is not surprising given the higher amount of NO produced at this location (Erwin et al., 2006). In quiescent or unstimulated endothelial cells, eNOS is predominantly S-nitrosylated on Cys-94 and Cys-99 (Dudzinski et al., 2006). Agonist stimulation promotes the rapid denitrosylation of eNOS and this occurs within a similar time frame to increased phosphorylation at Ser-1179 (Erwin et al., 2005). The nitrosylated cysteines are present within the zinc tetrathiolate cluster, a structure that is intimately connected with the eNOS dimer interface, but mutation of these sites does not impact dimer formation in intact cells (Erwin et al., 2005). Thus, the mechanism of exactly how nitrosylation represses the activity of eNOS remains poorly understood.

\section{PROTEIN ACETYLATION}

The ability of aspirin and acetylating analogs to activate eNOS was due to direct acetylation of eNOS protein (Taubert et al., 2004). Deacetlyation of eNOS, acetylated at lysine 609 is mediated by histone deacetylase 3 (HDAC3), which decreases NO production by reduced calmodulin association (Jung et al., 2010). Sirtuin1 (SIRT1) also has been shown to regulate eNOS acetylation and inactivation of Sirt1 by oxidants can increase eNOS acetylation (Arunachalam et al., 2010; Donato et al., 2011). eNOS is also nitrated on multiple tyrosines (Zickus et al., 2008) and peroxynitrite inactivates eNOS by inducing uncoupling (Zou et al., 2002).

In summary, NO is a highly diffusible, gaseous signaling molecule that influences organ function by a number of different mechanisms. The synthesis of NO in the cardiovascular system is highly regulated through a complex array of transcriptional and post-translational modifications.

NO-dependent signaling becomes corrupted in CVDs states and occurs alongside progressive vascular dysfunction. The extensive knowledge on eNOS regulation, as detailed in this review, will enable a more insightful identification of variables that can be modified to restore NO balance in CVD states.

\section{ACKNOWLEDGMENTS}

This work was supported by NIH grants P01 HL101902.

\section{REFERENCES}

Abu-Soud, H. M., Yoho, L. L., and Stuehr, D. J. (1994). Calmodulin controls neuronal nitric-oxide synthase by a dual mechanism. Activation of intra- and interdomain electron transfer. J. Biol. Chem. 269, 32047-32050.

Arunachalam, G., Yao, H., Sundar, I. K., Caito, S., and Rahman, I. (2010). SIRT1 regulates oxidant- and cigarette smoke-induced eNOS acetylation in endothelial cells: role of resveratrol. Biochem. Biophys. Res. Commun. 393, 66-72. doi: 10.1016/j.bbrc.2010.01.080

Balligand, J. L., Ungureanu-Longrois, D., Simmons, W. W., Pimental, D., Malinski, T. A., Kapturczak, M., et al. (1994). Cytokine-inducible nitric oxide synthase (iNOS) expression in cardiac myocytes. Characterization and regulation of iNOS expression and detection of iNOS activity in single cardiac myocytes in vitro. J. Biol. Chem. 269, 27580-27588.

Bauer, P. M., Fulton, D., Boo, Y. C., Sorescu, G. P., Kemp, B. E., Jo, H., et al. (2003). Compensatory phosphorylation and protein-protein interactions revealed by loss of function and gain of function mutants of multiple serine phosphorylation sites in endothelial nitric-oxide synthase. J. Biol. Chem. 278, 14841-14849. doi: 10.1074/jbc.M211926200

Beckman, J. S., and Koppenol, W. H. (1996). Nitric oxide, superoxide, and peroxynitrite: the good, the bad, and ugly. Am. J. Physiol. 271(5 Pt 1), C1424-C1437.

Benhar, M., Forrester, M. T., Hess, D. T., and Stamler, J. S. (2008). Regulated protein denitrosylation by cytosolic and mitochondrial thioredoxins. Science 320, 1050-1054. doi: 10.1126/science.1158265

Berkowitz, D. E., White, R., Li, D., Minhas, K. M., Cernetich, A., Kim, S., et al. (2003). Arginase reciprocally regulates nitric oxide synthase activity and contributes to endothelial dysfunction in aging blood vessels. Circulation 108, 2000-2006. doi: 10.1161/01.CIR.0000092948.04444.C7

Bernatchez, P., Sharma, A., Bauer, P. M., Marin, E., and Sessa, W. C. (2011). A noninhibitory mutant of the caveolin-1 scaffolding domain enhances eNOSderived NO synthesis and vasodilation in mice. J. Clin. Invest. 121, 3747-3755. doi: 10.1172/JCI44778

Bian, K., Doursout, M. F., and Murad, F. (2008). Vascular system: role of nitric oxide in cardiovascular diseases. J. Clin. Hypertens. (Greenwich) 10, 304-310. doi: 10.1111/j.1751-7176.2008.06632.x 
Billecke, S. S., Draganov, D. I., Morishima, Y., Murphy, P. J., Dunbar, A. Y., Pratt, W. B., et al. (2004). The role of hsp90 in heme-dependent activation of apo-neuronal nitric-oxide synthase. J. Biol. Chem. 279, 30252-30258. doi: 10.1074/jbc.M403864200

Blair, A., Shaul, P. W., Yuhanna, I. S., Conrad, P. A., and Smart, E. J. (1999). Oxidized low density lipoprotein displaces endothelial nitric-oxide synthase (eNOS) from plasmalemmal caveolae and impairs eNOS activation. J. Biol. Chem. 274, 32512-32519. doi: 10.1074/jbc.274.45.32512

Boo, Y. C., Hwang, J., Sykes, M., Michell, B. J., Kemp, B. E., Lum, H., et al. (2002). Shear stress stimulates phosphorylation of eNOS at Ser(635) by a protein kinase A-dependent mechanism. Am. J. Physiol. Heart Circ. Physiol. 283, H1819-H1828. doi: 10.1152/ajpheart.00214.2002

Bouloumie, A., Schini-Kerth, V. B., and Busse, R. (1999). Vascular endothelial growth factor up-regulates nitric oxide synthase expression in endothelial cells. Cardiovasc. Res. 41, 773-780. doi: 10.1016/S0008-6363(98)00228-4

Brodsky, S. V., Gao, S., Li, H., and Goligorsky, M. S. (2002). Hyperglycemic switch from mitochondrial nitric oxide to superoxide production in endothelial cells. Am. J. Physiol. Heart Circ. Physiol. 283, H2130-H2139. doi: 10.1152/ajpheart.00196.2002

Bucci, M., Gratton, J. P., Rudic, R. D., Acevedo, L., Roviezzo, F., Cirino, G., et al. (2000). In vivo delivery of the caveolin-1 scaffolding domain inhibits nitric oxide synthesis and reduces inflammation. Nat. Med. 6, 1362-1367. doi: $10.1038 / 82176$

Butt, E., Bernhardt, M., Smolenski, A., Kotsonis, P., Frohlich, L. G., Sickmann, A., et al. (2000). Endothelial nitric-oxide synthase (type III) is activated and becomes calcium independent upon phosphorylation by cyclic nucleotide-dependent protein kinases. J. Biol. Chem. 275, 5179-5187. doi: 10.1074/jbc.275.7.5179

Buys, E. S., Sips, P., Vermeersch, P., Raher, M. J., Rogge, E., Ichinose, F., et al. (2008). Gender-specific hypertension and responsiveness to nitric oxide in sGCalphal knockout mice. Cardiovasc. Res. 79, 179-186. doi: 10.1093/cvr/cvn068

Cao, S., Yao, J., McCabe, T. J., Yao, Q., Katusic, Z. S., Sessa, W. C., et al. (2001). Direct interaction between endothelial nitric-oxide synthase and dynamin-2. Implications for nitric-oxide synthase function. J. Biol. Chem. 276, 14249-14256. doi: 10.1074/jbc.M006258200

Chen, F., Lucas, R., and Fulton, D. (2013). The subcellular compartmentalization of arginine metabolizing enzymes and their role in endothelial dysfunction. Front. Immunol. 4:184. doi: 10.3389/fimmu.2013.00184

Chen, Z. P., Mitchelhill, K. I., Michell, B. J., Stapleton, D., Rodriguez-Crespo, I., Witters, L. A., et al. (1999). AMP-activated protein kinase phosphorylation of endothelial NO synthase. FEBS Lett. 443, 285-289. doi: 10.1016/S00145793(98)01705-0

Cho, D. H., Nakamura, T., Fang, J., Cieplak, P., Godzik, A., Gu, Z., et al. (2009). Snitrosylation of Drp1 mediates beta-amyloid-related mitochondrial fission and neuronal injury. Science 324, 102-105. doi: 10.1126/science.1171091

Church, J. E., and Fulton, D. (2006). Differences in eNOS activity because of subcellular localization are dictated by phosphorylation state rather than the local calcium environment. J. Biol. Chem. 281, 1477-1488. doi: 10.1074/jbc.M505968200

Cines, D. B., Pollak, E. S., Buck, C. A., Loscalzo, J., Zimmerman, G. A., McEver, R. P., et al. (1998). Endothelial cells in physiology and in the pathophysiology of vascular disorders. Blood 91, 3527-3561.

Corson, M. A., James, N. L., Latta, S. E., Nerem, R. M., Berk, B. C., and Harrison, D. G. (1996). Phosphorylation of endothelial nitric oxide synthase in response to fluid shear stress. Circ. Res. 79, 984-991. doi: 10.1161/01.RES.79.5.984

Dangel, O., Mergia, E., Karlisch, K., Groneberg, D., Koesling, D., and Friebe, A. (2010). Nitric oxide-sensitive guanylyl cyclase is the only nitric oxide receptor mediating platelet inhibition. J. Thromb. Haemost. 8, 1343-1352. doi: 10.1111/j.1538-7836.2010.03806.x

Dedio, J., Konig, P., Wohlfart, P., Schroeder, C., Kummer, W., and Muller-Esterl, W. (2001). NOSIP, a novel modulator of endothelial nitric oxide synthase activity. FASEB J. 15, 79-89. doi: 10.1096/fj.00-0078com

Dimmeler, S., Fleming, I., Fisslthaler, B., Hermann, C., Busse, R., and Zeiher, A. M. (1999). Activation of nitric oxide synthase in endothelial cells by Akt-dependent phosphorylation. Nature 399, 601-605. doi: 10.1038/21224

Dimmeler, S., Haendeler, J., Nehls, M., and Zeiher, A. M. (1997). Suppression of apoptosis by nitric oxide via inhibition of interleukin-1beta-converting enzyme (ICE)-like and cysteine protease protein (CPP)-32-like proteases. J. Exp. Med. 185, 601-607. doi: 10.1084/jem.185.4.601
Donato, A. J., Magerko, K. A., Lawson, B. R., Durrant, J. R., Lesniewski, L. A., and Seals, D. R. (2011). SIRT-1 and vascular endothelial dysfunction with ageing in mice and humans. J. Physiol. 589(Pt 18), 4545-4554. doi: 10.1113/jphysiol.2011.211219

Drab, M., Verkade, P., Elger, M., Kasper, M., Lohn, M., Lauterbach, B., et al. (2001). Loss of caveolae, vascular dysfunction, and pulmonary defects in caveolin-1 gene-disrupted mice. Science 293, 2449-2452. doi: 10.1126/science. 1062688

Drew, B. G., Fidge, N. H., Gallon-Beaumier, G., Kemp, B. E., and Kingwell, B. A. (2004). High-density lipoprotein and apolipoprotein AI increase endothelial NO synthase activity by protein association and multisite phosphorylation. Proc. Natl. Acad. Sci. U.S.A. 101, 6999-7004. doi: 10.1073/pnas. 0306266101

Drexler, H., Zeiher, A. M., Meinzer, K., and Just, H. (1991). Correction of endothelial dysfunction in coronary microcirculation of hypercholesterolaemic patients by L-arginine. Lancet 338, 1546-1550. doi: 10.1016/0140-6736(91)92372-9

Dudzinski, D. M., Igarashi, J., Greif, D., and Michel, T. (2006). The regulation and pharmacology of endothelial nitric oxide synthase. Annu. Rev. Pharmacol. Toxicol. 46, 235-276. doi: 10.1146/annurev.pharmtox.44.101802.121844

Elms, S., Chen, F., Wang, Y., Qian, J., Askari, B., Pandey, D., et al. (2013). Insights into the arginine paradox: evidence against the importance of subcellular location of arginase and eNOS. Am. J. Physiol. Heart Circ. Physiol. 305, H651-H666. doi: 10.1152/ajpheart.00755.2012

Erwin, P. A., Lin, A. J., Golan, D. E., and Michel, T. (2005). Receptorregulated dynamic S-nitrosylation of endothelial nitric-oxide synthase in vascular endothelial cells. J. Biol. Chem. 280, 19888-19894. doi: 10.1074/jbc.M413058200

Erwin, P. A., Mitchell, D. A., Sartoretto, J., Marletta, M. A., and Michel, T. (2006). Subcellular targeting and differential S-nitrosylation of endothelial nitric-oxide synthase. J. Biol. Chem. 281, 151-157. doi: 10.1074/jbc.M510421200

Feng, Y., Venema, V. J., Venema, R. C., Tsai, N., and Caldwell, R. B. (1999). VEGF induces nuclear translocation of Flk-1/KDR, endothelial nitric oxide synthase, and caveolin-1 in vascular endothelial cells. Biochem. Biophys. Res. Commun. 256, 192-197. doi: 10.1006/bbrc.1998.9790

Fisslthaler, B., Loot, A. E., Mohamed, A., Busse, R., and Fleming, I. (2008). Inhibition of endothelial nitric oxide synthase activity by proline-rich tyrosine kinase 2 in response to fluid shear stress and insulin. Circ. Res. 102, 1520-1528. doi: 10.1161/CIRCRESAHA.108.172072

Fleming, I., and Busse, R. (1999). Signal transduction of eNOS activation. Cardiovasc. Res. 43, 532-541. doi: 10.1016/S0008-6363(99)00094-2

Fleming, I., and Busse, R. (2003). Molecular mechanisms involved in the regulation of the endothelial nitric oxide synthase. Am. J. Physiol. Regul. Integr. Comp. Physiol. 284, R1-R12. doi: 10.1152/ajpregu.00323.2002

Fleming, I., Fisslthaler, B., Dimmeler, S., Kemp, B. E., and Busse, R. (2001). Phosphorylation of $\operatorname{Thr}(495)$ regulates $\mathrm{Ca}(2+) /$ calmodulin-dependent endothelial nitric oxide synthase activity. Circ. Res. 88, E68-E75. doi: 10.1161/hh1101.092677

Forstermann, U., and Munzel, T. (2006). Endothelial nitric oxide synthase in vascular disease: from marvel to menace. Circulation 113, 1708-1714. doi: 10.1161/CIRCULATIONAHA.105.602532

Forstermann, U., and Sessa, W. C. (2012). Nitric oxide synthases: regulation and function. Eur. Heart J. 33, 829-837, 837a-837d. doi: 10.1093/eurheartj/ehr304

Foster, M. W., Forrester, M. T., and Stamler, J. S. (2009a). A protein microarraybased analysis of S-nitrosylation. Proc. Natl. Acad. Sci. U.S.A. 106, 18948-18953. doi: 10.1073/pnas.0900729106

Foster, M. W., Hess, D. T., and Stamler, J. S. (2009b). Protein S-nitrosylation in health and disease: a current perspective. Trends Mol. Med. 15, 391-404. doi: 10.1016/j.molmed.2009.06.007

Friebe, A., and Koesling, D. (2003). Regulation of nitric oxide-sensitive guanylyl cyclase. Circ. Res. 93, 96-105. doi: 10.1161/01.RES.0000082524.34487.31

Friebe, A., Mergia, E., Dangel, O., Lange, A., and Koesling, D. (2007). Fatal gastrointestinal obstruction and hypertension in mice lacking nitric oxidesensitive guanylyl cyclase. Proc. Natl. Acad. Sci. U.S.A. 104, 7699-7704. doi: 10.1073/pnas.0609778104

Fulton, D., Babbitt, R., Zoellner, S., Fontana, J., Acevedo, L., McCabe, T. J., et al. (2004). Targeting of endothelial nitric-oxide synthase to the cytoplasmic face of the Golgi complex or plasma membrane regulates Akt- versus calciumdependent mechanisms for nitric oxide release. J. Biol. Chem. 279, 30349-30357. doi: 10.1074/jbc.M402155200 
Fulton, D., Church, J. E., Ruan, L., Li, C., Sood, S. G., Kemp, B. E., et al. (2005). Src kinase activates endothelial nitric-oxide synthase by phosphorylating Tyr83. J. Biol. Chem. 280, 35943-35952. doi: 10.1074/jbc.M504606200

Fulton, D., Fontana, J., Sowa, G., Gratton, J. P., Lin, M., Li, K. X., et al. (2002). Localization of endothelial nitric-oxide synthase phosphorylated on serine 1179 and nitric oxide in Golgi and plasma membrane defines the existence of two pools of active enzyme. J. Biol. Chem. 277, 4277-4284. doi: 10.1074/jbc.M106302200

Fulton, D., Gratton, J. P., McCabe, T. J., Fontana, J., Fujio, Y., Walsh, K., et al. (1999). Regulation of endothelium-derived nitric oxide production by the protein kinase Akt. Nature 399, 597-601. doi: 10.1038/21218

Fulton, D., Gratton, J. P., and Sessa, W. C. (2001). Post-translational control of endothelial nitric oxide synthase: why isn't calcium/calmodulin enough? J. Pharmacol. Exp. Ther. 299, 818-824.

Fulton, D., Ruan, L., Sood, S. G., Li, C., Zhang, Q., and Venema, R. C. (2008). Agonist-stimulated endothelial nitric oxide synthase activation and vascular relaxation. Role of eNOS phosphorylation at Tyr83. Circ. Res. 102, 497-504. doi: 10.1161/CIRCRESAHA.107.162933

Furchgott, R. F., and Zawadzki, J. V. (1980). The obligatory role of endothelial cells in the relaxation of arterial smooth muscle by acetylcholine. Nature 288, 373-376. doi: 10.1038/288373a0

Gallis, B., Corthals, G. L., Goodlett, D. R., Ueba, H., Kim, F., Presnell, S. R., et al. (1999). Identification of flow-dependent endothelial nitric-oxide synthase phosphorylation sites by mass spectrometry and regulation of phosphorylation and nitric oxide production by the phosphatidylinositol 3-kinase inhibitor LY29. J. Biol. Chem. 274, 30101-30108. doi: 10.1074/jbc.274.42.30101

Gangopahyay, A., Oran, M., Bauer, E. M., Wertz, J. W., Comhair, S. A., Erzurum, S. C., et al. (2011). Bone morphogenetic protein receptor II is a novel mediator of endothelial nitric-oxide synthase activation. J. Biol. Chem. 286, 33134-33140. doi: 10.1074/jbc.M111.274100

Gao, S., Chen, J., Brodsky, S. V., Huang, H., Adler, S., Lee, J. H., et al. (2004). Docking of endothelial nitric oxide synthase (eNOS) to the mitochondrial outer membrane: a pentabasic amino acid sequence in the autoinhibitory domain of eNOS targets a proteinase K-cleavable peptide on the cytoplasmic face of mitochondria. J. Biol. Chem. 279, 15968-15974. doi: 10.1074/jbc.M308504200

Garcia-Cardena, G., Fan, R., Shah, V., Sorrentino, R., Cirino, G., Papapetropoulos, A., et al. (1998). Dynamic activation of endothelial nitric oxide synthase by Hsp90. Nature 392, 821-824. doi: 10.1038/33934

Garcia-Cardena, G., Fan, R., Stern, D. F., Liu, J., and Sessa, W. C. (1996a). Endothelial nitric oxide synthase is regulated by tyrosine phosphorylation and interacts with caveolin-1. J. Biol. Chem. 271, 27237-27240. doi: 10.1074/jbc.271.44.27237

Garcia-Cardena, G., Oh, P., Liu, J., Schnitzer, J. E., and Sessa, W. C. (1996b). Targeting of nitric oxide synthase to endothelial cell caveolae via palmitoylation: implications for nitric oxide signaling. Proc. Natl. Acad. Sci. U.S.A. 93, 6448-6453. doi: 10.1073/pnas.93.13.6448

Garcia-Cardena, G., Martasek, P., Masters, B. S., Skidd, P. M., Couet, J., Li, S., et al. (1997). Dissecting the interaction between nitric oxide synthase (NOS) and caveolin. Functional significance of the nos caveolin binding domain in vivo. J. Biol. Chem. 272, 25437-25440. doi: 10.1074/jbc.272.41.25437

Ghosh, A., and Stuehr, D. J. (2012). Soluble guanylyl cyclase requires heat shock protein 90 for heme insertion during maturation of the NO-active enzyme. Proc. Natl. Acad. Sci. U.S.A. 109, 12998-13003. doi: 10.1073/pnas.1205854109

Gomez-Fernandez, P., Perez-Requena, J., Sanchez-Margalet, V., Esteban, J., Murillo-Carretero, M., and Almaraz-Jimenez, M. (2005). [Vascular damage in chronic renal failure. The increase of vascular nitrotyrosine and cytochines accumulation is accompanied by an increase of endothelial nitric oxide synthase (eNOS) expression]. Nefrologia 25, 155-162.

Govers, R., van der Sluijs, P., van Donselaar, E., Slot, J. W., and Rabelink, T. J. (2002). Endothelial nitric oxide synthase and its negative regulator caveolin-1 localize to distinct perinuclear organelles. J. Histochem. Cytochem. 50, 779-788. doi: 10.1177/002215540205000604

Groneberg, D., Konig, P., Wirth, A., Offermanns, S., Koesling, D., and Friebe, A. (2010). Smooth muscle-specific deletion of nitric oxide-sensitive guanylyl cyclase is sufficient to induce hypertension in mice. Circulation 121, 401-409. doi: 10.1161/CIRCULATIONAHA.109.890962

Hallemeesch, M. M., Lamers, W. H., and Deutz, N. E. (2002). Reduced arginine availability and nitric oxide production. Clin. Nutr. 21, 273-279. doi: 10.1054/clnu.2002.0571
Harris, M. B., Bartoli, M., Sood, S. G., Matts, R. L., and Venema, R. C. (2006). Direct interaction of the cell division cycle 37 homolog inhibits endothelial nitric oxide synthase activity. Circ. Res. 98, 335-341. doi: 10.1161/01.RES.0000203564.54250.0b

Harris, M. B., Ju, H., Venema, V. J., Liang, H., Zou, R., Michell, B. J., et al. (2001). Reciprocal phosphorylation and regulation of endothelial nitric-oxide synthase in response to bradykinin stimulation. J. Biol. Chem. 276, 16587-16591. doi: 10.1074/jbc.M100229200

Heitzer, T., Brockhoff, C., Mayer, B., Warnholtz, A., Mollnau, H., Henne, S., et al. (2000). Tetrahydrobiopterin improves endothelium-dependent vasodilation in chronic smokers: evidence for a dysfunctional nitric oxide synthase. Circ. Res. 86, E36-E41. doi: 10.1161/01.RES.86.2.e36

Heron, M., Hoyert, D. L., Murphy, S. L., Xu, J., Kochanek, K. D., and Tejada-Vera, B. (2009). Deaths: final data for (2006). Natl. Vital Stat. Rep. 57, 1-80.

Hess, D. T., Matsumoto, A., Kim, S. O., Marshall, H. E., and Stamler, J. S. (2005). Protein S-nitrosylation: purview and parameters. Nat. Rev. Mol. Cell Biol. 6, 150-166. doi: 10.1038/nrm1569

Hess, D. T., Matsumoto, A., Nudelman, R., and Stamler, J. S. (2001). S-nitrosylation: spectrum and specificity. Nat. Cell Biol. 3, E46-E49. doi: 10.1038/35055152

Higashi, Y., Sasaki, S., Nakagawa, K., Fukuda, Y., Matsuura, H., Oshima, T., et al. (2002). Tetrahydrobiopterin enhances forearm vascular response to acetylcholine in both normotensive and hypertensive individuals. Am. J. Hypertens. 15(4 Pt 1), 326-332. doi: 10.1016/S0895-7061(01)02317-2

Hong, H. J., Hsiao, G., Cheng, T. H., and Yen, M. H. (2001). Supplemention with tetrahydrobiopterin suppresses the development of hypertension in spontaneously hypertensive rats. Hypertension 38, 1044-1048. doi: 10.1161/hy1101.095331

Ignarro, L. J., Buga, G. M., Wei, L. H., Bauer, P. M., Wu, G., and del Soldato, P. (2001). Role of the arginine-nitric oxide pathway in the regulation of vascular smooth muscle cell proliferation. Proc. Natl. Acad. Sci. U.S.A. 98, 4202-4208. doi: 10.1073/pnas.071054698

Ignarro, L. J., Byrns, R. E., Buga, G. M., and Wood, K. S. (1987). Endotheliumderived relaxing factor from pulmonary artery and vein possesses pharmacologic and chemical properties identical to those of nitric oxide radical. Circ. Res. 61, 866-879. doi: 10.1161/01.RES.61.6.866

Imaizumi, T., Hirooka, Y., Masaki, H., Harada, S., Momohara, M., Tagawa, T., et al. (1992). Effects of L-arginine on forearm vessels and responses to acetylcholine. Hypertension 20, 511-517. doi: 10.1161/01.HYP.20.4.511

Iwakiri, Y., Satoh, A., Chatterjee, S., Toomre, D. K., Chalouni, C. M., Fulton, D., et al. (2006). Nitric oxide synthase generates nitric oxide locally to regulate compartmentalized protein S-nitrosylation and protein trafficking. Proc. Natl. Acad. Sci. U.S.A. 103, 19777-19782. doi: 10.1073/pnas.0605907103

Jagnandan, D., Sessa, W. C., and Fulton, D. (2005). Intracellular location regulates calcium-calmodulin-dependent activation of organelle-restricted eNOS. Am. J. Physiol. Cell Physiol. 289, C1024-C1033. doi: 10.1152/ajpcell.00162.2005

Jensovsky, J. (1994). [Endothelins. I. Physiology]. Cas. Lek. Cesk. 133, 46-49.

Jiang, J., Cyr, D., Babbitt, R. W., Sessa, W. C., and Patterson, C. (2003). Chaperonedependent regulation of endothelial nitric-oxide synthase intracellular trafficking by the co-chaperone/ubiquitin ligase CHIP. J. Biol. Chem. 278, 49332-49341. doi: 10.1074/jbc.M304738200

Jung, S. B., Kim, C. S., Naqvi, A., Yamamori, T., Mattagajasingh, I., Hoffman, T. A., et al. (2010). Histone deacetylase 3 antagonizes aspirin-stimulated endothelial nitric oxide production by reversing aspirin-induced lysine acetylation of endothelial nitric oxide synthase. Circ. Res. 107, 877-887. doi: 10.1161/CIRCRESAHA.110.222968

Kang-Decker, N., Cao, S., Chatterjee, S., Yao, J., Egan, L. J., Semela, D., et al. (2007). Nitric oxide promotes endothelial cell survival signaling through Snitrosylation and activation of dynamin-2. J. Cell. Sci. 120(Pt 3), 492-501. doi: $10.1242 /$ jcs. 03361

Katsuki, S., and Murad, F. (1977). Regulation of adenosine cyclic 3', 5'monophosphate and guanosine cyclic 3', 5'-monophosphate levels and contractility in bovine tracheal smooth muscle. Mol. Pharmacol. 13, 330-341.

Kibbe, M., Billiar, T., and Tzeng, E. (1999). Inducible nitric oxide synthase and vascular injury. Cardiovasc. Res. 43, 650-657. doi: 10.1016/S0008-6363(99) 00130-3

Kondrikov, D., Fonseca, F. V., Elms, S., Fulton, D., Black, S. M., Block, E. R., et al. (2010). Beta-actin association with endothelial nitric-oxide synthase modulates nitric oxide and superoxide generation from the enzyme. J. Biol. Chem. 285, 4319-4327. doi: 10.1074/jbc.M109.063172 
Kou, R., Greif, D., and Michel, T. (2002). Dephosphorylation of endothelial nitricoxide synthase by vascular endothelial growth factor. Implications for the vascular responses to cyclosporin A. J. Biol. Chem. 277, 29669-29673. doi: 10.1074/jbc.M204519200

Kroncke, K. D., Fehsel, K., and Kolb-Bachofen, V. (1998). Inducible nitric oxide synthase in human diseases. Clin. Exp. Immunol. 113, 147-156. doi: 10.1046/j.1365-2249.1998.00648.x

Kuhlencordt, P. J., Gyurko, R., Han, F., Scherrer-Crosbie, M., Aretz, T. H., Hajjar, R., et al. (2001). Accelerated atherosclerosis, aortic aneurysm formation, and ischemic heart disease in apolipoprotein E/endothelial nitric oxide synthase double-knockout mice. Circulation 104, 448-454. doi: 10.1161/hc2901.091399

Li, C., Huang, W., Harris, M. B., Goolsby, J. M., and Venema, R. C. (2005). Interaction of the endothelial nitric oxide synthase with the CAT-1 arginine transporter enhances NO release by a mechanism not involving arginine transport. Biochem. J. 386(Pt 3), 567-574. doi: 10.1042/BJ20041005

Li, C., Ruan, L., Sood, S. G., Papapetropoulos, A., Fulton, D., and Venema, R. C. (2007). Role of eNOS phosphorylation at Ser-116 in regulation of eNOS activity in endothelial cells. Vascul. Pharmacol. 47, 257-264. doi: 10.1016/j.vph.2007.07.001

Lim, K. H., Ancrile, B. B., Kashatus, D. F., and Counter, C. M. (2008). Tumour maintenance is mediated by eNOS. Nature 452, 646-649. doi: 10.1038/nature06778

Lima, B., Forrester, M. T., Hess, D. T., and Stamler, J. S. (2010). Snitrosylation in cardiovascular signaling. Circ. Res. 106, 633-646. doi: 10.1161/CIRCRESAHA.109.207381

Lisanti, M. P., Scherer, P. E., Tang, Z., and Sargiacomo, M. (1994). Caveolae, caveolin and caveolin-rich membrane domains: a signalling hypothesis. Trends Cell Biol. 4, 231-235. doi: 10.1016/0962-8924(94)90114-7

Liu, J., Garcia-Cardena, G., and Sessa, W. C. (1995). Biosynthesis and palmitoylation of endothelial nitric oxide synthase: mutagenesis of palmitoylation sites, cysteines-15 and/or -26, argues against depalmitoylation-induced translocation of the enzyme. Biochemistry 34, 12333-12340. doi: 10.1021/bi00038a029

Liu, J., Hughes, T. E., and Sessa, W. C. (1997). The first 35 amino acids and fatty acylation sites determine the molecular targeting of endothelial nitric oxide synthase into the Golgi region of cells: a green fluorescent protein study. J. Cell Biol. 137, 1525-1535. doi: 10.1083/jcb.137.7.1525

Liu, J., and Sessa, W. C. (1994). Identification of covalently bound aminoterminal myristic acid in endothelial nitric oxide synthase. J. Biol. Chem. 269, 11691-11694.

Liu, L., Hausladen, A., Zeng, M., Que, L., Heitman, J., and Stamler, J. S. (2001). A metabolic enzyme for S-nitrosothiol conserved from bacteria to humans. Nature 410, 490-494. doi: 10.1038/35068596

Liu, L., Yan, Y., Zeng, M., Zhang, J., Hanes, M. A., Ahearn, G., et al. (2004). Essential roles of S-nitrosothiols in vascular homeostasis and endotoxic shock. Cell 116, 617-628. doi: 10.1016/S0092-8674(04)00131-X

Liu, S., Premont, R. T., and Rockey, D. C. (2012). G-protein-coupled receptor kinase interactor-1 (GIT1) is a new endothelial nitric-oxide synthase (eNOS) interactor with functional effects on vascular homeostasis. J. Biol. Chem. 287, 12309-12320. doi: 10.1074/jbc.M111.320465

Loot, A. E., Schreiber, J. G., Fisslthaler, B., and Fleming, I. (2009). Angiotensin II impairs endothelial function via tyrosine phosphorylation of the endothelial nitric oxide synthase. J. Exp. Med. 206, 2889-2896. doi: 10.1084/jem.20090449

Martinez-Ruiz, A., and Lamas, S. (2005). Nitrosylation of thiols in vascular homeostasis and disease. Curr. Atheroscler. Rep. 7, 213-218. doi: 10.1007/s11883-0050009-1

Matsushita, K., Morrell, C. N., Cambien, B., Yang, S. X., Yamakuchi, M., Bao, C., et al. (2003). Nitric oxide regulates exocytosis by S-nitrosylation of N-ethylmaleimide-sensitive factor. Cell 115, 139-150. doi: 10.1016/S00928674(03)00803-1

McCabe, T. J., Fulton, D., Roman, L. J., and Sessa, W. C. (2000). Enhanced electron flux and reduced calmodulin dissociation may explain calcium-independent eNOS activation by phosphorylation. J. Biol. Chem. 275, 6123-6128. doi: 10.1074/jbc.275.9.6123

Michel, J. B., Feron, O., Sase, K., Prabhakar, P., and Michel, T. (1997). Caveolin versus calmodulin. Counterbalancing allosteric modulators of endothelial nitric oxide synthase. J. Biol. Chem. 272, 25907-25912. doi: 10.1074/jbc.272.41.25907

Michel, T., Li, G. K., and Busconi, L. (1993). Phosphorylation and subcellular translocation of endothelial nitric oxide synthase. Proc. Natl. Acad. Sci. U.S.A. 90, 6252-6256. doi: 10.1073/pnas.90.13.6252
Michell, B. J., Chen, Z., Tiganis, T., Stapleton, D., Katsis, F., Power, D. A., et al. (2001). Coordinated control of endothelial nitric-oxide synthase phosphorylation by protein kinase $\mathrm{C}$ and the cAMP-dependent protein kinase. J. Biol. Chem. 276, 17625-17628. doi: 10.1074/jbc.C100122200

Michell, B. J., Griffiths, J. E., Mitchelhill, K. I., Rodriguez-Crespo, I., Tiganis, T., Bozinovski, S., et al. (1999). The Akt kinase signals directly to endothelial nitric oxide synthase. Curr. Biol. 9, 845-848. doi: 10.1016/S0960-9822(99) 80371-6

Michell, B. J., Harris, M. B., Chen, Z. P., Ju, H., Venema, V. J., Blackstone, M. A., et al. (2002). Identification of regulatory sites of phosphorylation of the bovine endothelial nitric-oxide synthase at serine 617 and serine 635. J. Biol. Chem. 277, 42344-42351. doi: 10.1074/jbc.M205144200

Ming, X. F., Barandier, C., Viswambharan, H., Kwak, B. R., Mach, F., Mazzolai, L., et al. (2004). Thrombin stimulates human endothelial arginase enzymatic activity via RhoA/ROCK pathway: implications for atherosclerotic endothelial dysfunction. Circulation 110, 3708-3714. doi: 10.1161/01.CIR.0000142867.26182.32

Mitchell, D. A., and Marletta, M. A. (2005). Thioredoxin catalyzes the Snitrosation of the caspase-3 active site cysteine. Nat. Chem. Biol. 1, 154-158. doi: $10.1038 /$ nchembio720

Mizuno, Y., Jacob, R. F. and Mason, R. P. (2010). Advances in pharmacologic modulation of nitric oxide in hypertension. Curr. Cardiol. Rep. 12, 472-480. doi: 10.1007/S11886-010-0142-5

Mount, P. F., Kemp, B. E., and Power, D. A. (2007). Regulation of endothelial and myocardial NO synthesis by multi-site eNOS phosphorylation. J. Mol. Cell. Cardiol. 42, 271-279. doi: 10.1016/j.yjmcc.2006.05.023

Murad, F. (1986). Cyclic guanosine monophosphate as a mediator of vasodilation. J. Clin. Invest. 78, 1-5. doi: 10.1172/JCI112536

Nuszkowski, A., Grabner, R., Marsche, G., Unbehaun, A., Malle, E., and Heller, R. (2001). Hypochlorite-modified low density lipoprotein inhibits nitric oxide synthesis in endothelial cells via an intracellular dislocalization of endothelial nitric-oxide synthase. J. Biol. Chem. 276, 14212-14221.

Oemar, B. S., Tschudi, M. R., Godoy, N., Brovkovich, V., Malinski, T., and Luscher, T. F. (1998). Reduced endothelial nitric oxide synthase expression and production in human atherosclerosis. Circulation 97, 2494-2498. doi: 10.1161/01.CIR.97.25.2494

Ou, J., Fontana, J. T., Ou, Z., Jones, D. W., Ackerman, A. W., Oldham, K. T., et al. (2004). Heat shock protein 90 and tyrosine kinase regulate eNOS NO* generation but not $\mathrm{NO}^{\star}$ bioactivity. Am. J. Physiol. Heart Circ. Physiol. 286, H561-H569. doi: 10.1152/ajpheart.00736.2003

Ou, J., Ou, Z., Ackerman, A. W., Oldham, K. T., and Pritchard, Jr. K. A. (2003). Inhibition of heat shock protein 90 (hsp90) in proliferating endothelial cells uncouples endothelial nitric oxide synthase activity. Free Radic. Biol. Med. 34, 269-276. doi: 10.1016/S0891-5849(02)01299-6

Ozaki, M., Kawashima, S., Yamashita, T., Hirase, T., Namiki, M., Inoue, N., et al. (2002). Overexpression of endothelial nitric oxide synthase accelerates atherosclerotic lesion formation in apoE-deficient mice. J. Clin. Invest. 110, 331-340. doi: 10.1172/JCI15215

Ozawa, K., Whalen, E. J., Nelson, C. D., Mu, Y., Hess, D. T., Lefkowitz, R. J., et al. (2008). S-nitrosylation of beta-arrestin regulates beta-adrenergic receptor trafficking. Mol. Cell 31, 395-405. doi: 10.1016/j.molcel.2008.05.024

Palmer, L. A., Gaston, B., and Johns, R. A. (2000). Normoxic stabilization of hypoxia-inducible factor-1 expression and activity: redox-dependent effect of nitrogen oxides. Mol. Pharmacol. 58, 1197-1203. doi: 10.1124/mol.58.6.1197

Palmer, R. M., Ferrige, A. G., and Moncada, S. (1987). Nitric oxide release accounts for the biological activity of endothelium-derived relaxing factor. Nature 327, 524-526. doi: 10.1038/327524a0

Panda, K., Rosenfeld, R. J., Ghosh, S., Meade, A. L., Getzoff, E. D., and Stuehr, D. J. (2002). Distinct dimer interaction and regulation in nitric-oxide synthase types I, II, and III. J. Biol. Chem. 277, 31020-31030. doi: 10.1074/jbc.M203749200

Pieper, G. M. (1997). Acute amelioration of diabetic endothelial dysfunction with a derivative of the nitric oxide synthase cofactor, tetrahydrobiopterin. J. Cardiovasc. Pharmacol. 29, 8-15. doi: 10.1097/00005344-199701000-00002

Pieper, G. M., and Siebeneich, W. (1997). Diabetes-induced endothelial dysfunction is prevented by long-term treatment with the modified iron chelator, hydroxyethyl starch conjugated-deferoxamine. J. Cardiovasc. Pharmacol. 30, 734-738. doi: 10.1097/00005344-199712000-00006

Prabhakar, P., Cheng, V., and Michel, T. (2000). A chimeric transmembrane domain directs endothelial nitric-oxide synthase palmitoylation and 
targeting to plasmalemmal caveolae. J. Biol. Chem. 275, 19416-19421. doi: 10.1074/jbc.M001952200

Pratt, W. B. (1997). The role of the hsp90-based chaperone system in signal transduction by nuclear receptors and receptors signaling via MAP kinase. Annu. Rev. Pharmacol. Toxicol. 37, 297-326. doi: 10.1146/annurev.pharmtox.37.1.297

Pritchard, Jr. K. A., Ackerman, A. W., Gross, E. R., Stepp, D. W., Shi, Y., Fontana, J. T., et al. (2001). Heat shock protein 90 mediates the balance of nitric oxide and superoxide anion from endothelial nitricoxide synthase. J. Biol. Chem. 276, 17621-17624. doi: 10.1074/jbc. C100084200

Qian, J., and Fulton, D. J. (2012). Exogenous, but not endogenous nitric oxide inhibits adhesion molecule expression in human endothelial cells. Front. Physiol. 3:3. doi: 10.3389/fphys.2012.00003

Qian, J., Zhang, Q., Church, J. E., Stepp, D. W., Rudic, R. D., and Fulton, D. J. (2010). Role of local production of endothelium-derived nitric oxide on cGMP signaling and S-nitrosylation. Am. J. Physiol. Heart Circ. Physiol. 298, H112-H118. doi: 10.1152/ajpheart.00614.2009

Razani, B., Engelman, J. A., Wang, X. B., Schubert, W., Zhang, X. L., Marks, C. B., et al. (2001). Caveolin-1 null mice are viable but show evidence of hyperproliferative and vascular abnormalities. J. Biol. Chem. 276, 38121-38138. doi: 10.1074/jbc.M105408200

Robinson, L. J., and Michel, T. (1995). Mutagenesis of palmitoylation sites in endothelial nitric oxide synthase identifies a novel motif for dual acylation and subcellular targeting. Proc. Natl. Acad. Sci. U.S.A. 92, 11776-11780. doi: 10.1073/pnas.92.25.11776

Rossitch, Jr. E., Alexander, 3rd. E., Black, P. M., and Cooke, J. P. (1991). L-arginine normalizes endothelial function in cerebral vessels from hypercholesterolemic rabbits. J. Clin. Invest. 87, 1295-1299. doi: 10.1172/JCI115132

Roviezzo, F., Cuzzocrea, S., Di Lorenzo, A., Brancaleone, V., Mazzon, E., Di Paola, R., et al. (2007). Protective role of PI3-kinase-Akt-eNOS signalling pathway in intestinal injury associated with splanchnic artery occlusion shock. $\mathrm{Br}$. J. Pharmacol. 151, 377-383. doi: 10.1038/sj.bjp.0707233

Ruan, L., Torres, C. M., Buffett, R. J., Kennard, S., Fulton, D., and Venema, R. C. (2013). Calcineurin-mediated dephosphorylation of eNOS at serine 116 affects eNOS enzymatic activity indirectly by facilitating c-Src binding and tyrosine 83 phosphorylation. Vascul. Pharmacol. 59, 27-35. doi: 10.1016/j.vph.2013.05.004

Ruan, L., Torres, C. M., Qian, J., Chen, F., Mintz, J. D., Stepp, D. W., et al. (2011). Pin 1 prolyl isomerase regulates endothelial nitric oxide synthase. Arterioscler. Thromb. Vasc. Biol. 31, 392-398. doi: 10.1161/ATVBAHA.110.213181

Rudic, R. D., Shesely, E. G., Maeda, N., Smithies, O., Segal, S. S., and Sessa, W. C. (1998). Direct evidence for the importance of endothelium-derived nitric oxide in vascular remodeling. J. Clin. Invest. 101, 731-736. doi: 10.1172/JCI1699

Ruetten, H., Zabel, U., Linz, W., and Schmidt, H. H. (1999). Downregulation of soluble guanylyl cyclase in young and aging spontaneously hypertensive rats. Circ. Res. 85, 534-541. doi: 10.1161/01.RES.85.6.534

Russell, K. S., Haynes, M. P., Caulin-Glaser, T., Rosneck, J., Sessa, W. C., and Bender, J. R. (2000). Estrogen stimulates heat shock protein 90 binding to endothelial nitric oxide synthase in human vascular endothelial cells. Effects on calcium sensitivity and NO release. J. Biol. Chem. 275, 5026-5030. doi: 10.1074/jbc.275.7.5026

Russwurm, M., Behrends, S., Harteneck, C., and Koesling, D. (1998). Functional properties of a naturally occurring isoform of soluble guanylyl cyclase. Biochem. J. 335(Pt 1), 125-130.

Sangwung, P., Greco, T. M., Wang, Y., Ischiropoulos, H., Sessa, W. C., and Iwakiri, Y. (2012). Proteomic identification of S-nitrosylated Golgi proteins: new insights into endothelial cell regulation by eNOS-derived NO. PLOS ONE 7:e31564. doi: 10.1371/journal.pone.0031564

Scotland, R. S., Morales-Ruiz, M., Chen, Y., Yu, J., Rudic, R. D., Fulton, D., et al. (2002). Functional reconstitution of endothelial nitric oxide synthase reveals the importance of serine 1179 in endothelium-dependent vasomotion. Circ. Res. 90, 904-910. doi: 10.1161/01.RES.0000016506.04193.96

Sears, C. E., Bryant, S. M., Ashley, E. A., Lygate, C. A., Rakovic, S., Wallis, H. L., et al. (2003). Cardiac neuronal nitric oxide synthase isoform regulates myocardial contraction and calcium handling. Circ. Res. 92, e52-e59. doi: 10.1161/01.RES.0000064585.95749.6D

Sessa, W. C. (2004). eNOS at a glance. J. Cell. Sci. 117(Pt 12), 2427-2429. doi: $10.1242 /$ jcs. 01165

Seth, D., and Stamler, J. S. (2011). The SNO-proteome: causation and classifications. Curr. Opin. Chem. Biol. 15, 129-136. doi: 10.1016/j.cbpa.2010.10.012
Shaul, P. W. (2002). Regulation of endothelial nitric oxide synthase: location, location, location. Annu. Rev. Physiol. 64, 749-774. doi: 10.1146/annurev.physiol.64.081501.155952

Shaul, P. W., Smart, E. J., Robinson, L. J., German, Z., Yuhanna, I. S., Ying, Y., et al. (1996). Acylation targets emdothelial nitric-oxide synthase to plasmalemmal caveolae. J. Biol. Chem. 271, 6518-6522. doi: 10.1074/jbc.271.11.6518

Shen, B. Q., Lee, D. Y., and Zioncheck, T. F. (1999). Vascular endothelial growth factor governs endothelial nitric-oxide synthase expression via a KDR/Flk1 receptor and a protein kinase C signaling pathway. J. Biol. Chem. 274, 33057-33063. doi: 10.1074/jbc.274.46.33057

Shesely, E. G., Maeda, N., Kim, H. S., Desai, K. M., Krege, J. H., Laubach, V. E., et al. (1996). Elevated blood pressures in mice lacking endothelial nitric oxide synthase. Proc. Natl. Acad. Sci. U.S.A. 93, 13176-13181. doi: 10.1073/pnas.93.23.13176

Shinozaki, K., Kashiwagi, A., Nishio, Y., Okamura, T., Yoshida, Y., Masada, M., et al. (1999). Abnormal biopterin metabolism is a major cause of impaired endothelium-dependent relaxation through nitric oxide/O2- imbalance in insulin-resistant rat aorta. Diabetes 48, 2437-2445. doi: 10.2337/diabetes.48.12.2437

Shinozaki, K., Nishio, Y., Okamura, T., Yoshida, Y., Maegawa, H., Kojima, H., et al. (2000). Oral administration of tetrahydrobiopterin prevents endothelial dysfunction and vascular oxidative stress in the aortas of insulin-resistant rats. Circ. Res. 87, 566-573. doi: 10.1161/01.RES.87.7.566

Siddhanta, U., Presta, A., Fan, B., Wolan, D., Rousseau, D. L., and Stuehr, D. J. (1998). Domain swapping in inducible nitric-oxide synthase. Electron transfer occurs between flavin and heme groups located on adjacent subunits in the dimer. J. Biol. Chem. 273, 18950-18958. doi: 10.1074/jbc.273.30. 18950

Singel, D. J., and Stamler, J. S. (2005). Chemical physiology of blood flow regulation by red blood cells: the role of nitric oxide and S-nitrosohemoglobin. Annu. Rev. Physiol. 67, 99-145. doi: 10.1146/annurev.physiol.67.060603.090918

Smart, E. J., Graf, G. A., McNiven, M. A., Sessa, W. C., Engelman, J. A., Scherer, P. E., et al. (1999). Caveolins, liquid-ordered domains, and signal transduction. Mol. Cell. Biol. 19, 7289-7304.

Sowa, G., Pypaert, M., and Sessa, W. C. (2001). Distinction between signaling mechanisms in lipid rafts vs. caveolae. Proc. Natl. Acad. Sci. U.S.A. 98, 14072-14077. doi: 10.1073/pnas.241409998

Stamler, J. S., Lamas, S., and Fang, F. C. (2001). Nitrosylation. the prototypic redox-based signaling mechanism. Cell 106, 675-683. doi: 10.1016/S00928674(01)00495-0

Stroes, E., Kastelein, J., Cosentino, F., Erkelens, W., Wever, R., Koomans, H., et al. (1997). Tetrahydrobiopterin restores endothelial function in hypercholesterolemia. J. Clin. Invest. 99, 41-46. doi: 10.1172/JCI119131

Sun, J., and Liao, J. K. (2002). Functional interaction of endothelial nitric oxide synthase with a voltage-dependent anion channel. Proc. Natl. Acad. Sci. U.S.A. 99, 13108-13113. doi: 10.1073/pnas.202260999

Taubert, D., Berkels, R., Grosser, N., Schroder, H., Grundemann, D., and Schomig, E. (2004). Aspirin induces nitric oxide release from vascular endothelium: a novel mechanism of action. Br. J. Pharmacol. 143, 159-165. doi: 10.1038/sj.bjp.0705907

Taylor, S. Y., Dixon, H. M., Yoganayagam, S., Price, N., and Lang, D. (2013). Folic acid modulates eNOS activity via effects on posttranslational modifications and protein-protein interactions. Eur. J. Pharmacol. 714, 193-201. doi: 10.1016/j.ejphar.2013.05.026

Thomas, D. D., Liu, X., Kantrow, S. P., and Lancaster, Jr. J. R. (2001). The biological lifetime of nitric oxide: implications for the perivascular dynamics of NO and O2. Proc. Natl. Acad. Sci. U.S.A. 98, 355-360. doi: 10.1073/pnas.98. 1.355

Toda, N. (2012). Age-related changes in endothelial function and blood flow regulation. Pharmacol. Ther. 133, 159-176. doi: 10.1016/j.pharmthera.2011.10.004

Vasquez-Vivar, J., Kalyanaraman, B., Martasek, P., Hogg, N., Masters, B. S., Karoui, H., et al. (1998). Superoxide generation by endothelial nitric oxide synthase: the influence of cofactors. Proc. Natl. Acad. Sci. U.S.A. 95, 9220-9225. doi: 10.1073/pnas.95.16.9220

Venema, R. C. (2002). Post-translational mechanisms of endothelial nitric oxide synthase regulation by bradykinin. Int. Immunopharmacol. 2, 1755-1762. doi: 10.1016/S1567-5769(02)00185-6

Venema, R. C., Venema, V. J., Ju, H., Harris, M. B., Snead, C., Jilling, T., et al. (2003). Novel complexes of guanylate cyclase with heat shock protein 90 and 
nitric oxide synthase. Am. J. Physiol. Heart Circ. Physiol. 285, H669-H678. doi: 10.1152/ajpheart.01025.2002

Venema, V. J., Marrero, M. B., and Venema, R. C. (1996). Bradykinin-stimulated protein tyrosine phosphorylation promotes endothelial nitric oxide synthase translocation to the cytoskeleton. Biochem. Biophys. Res. Commun. 226, 703-710. doi: 10.1006/bbrc.1996.1417

Verhaar, M. C., Westerweel, P. E., van Zonneveld, A. J., and Rabelink, T. J. (2004). Free radical production by dysfunctional eNOS. Heart 90, 494-495. doi: 10.1136/hrt.2003.029405

Versari, D., Daghini, E., Virdis, A., Ghiadoni, L., and Taddei, S. (2009). Endothelial dysfunction as a target for prevention of cardiovascular disease. Diabetes Care 32(Suppl. 2), S314-S321. doi: 10.2337/dc09-S330

Wei, W., Li, B., Hanes, M. A., Kakar, S., Chen, X., and Liu, L. (2010). S-nitrosylation from GSNOR deficiency impairs DNA repair and promotes hepatocarcinogenesis. Sci. Transl. Med. 2, 19ra13. doi: 10.1126/scitranslmed.3000328

Wu, G., and Morris, Jr. S. M. (1998). Arginine metabolism: nitric oxide and beyond. Biochem. J. 336(Pt 1), 1-17.

Xu, H., Shi, Y., Wang, J., Jones, D., Weilrauch, D., Ying, R., et al. (2007). A heat shock protein 90 binding domain in endothelial nitric-oxide synthase influences enzyme function. J. Biol. Chem. 282, 37567-37574. doi: 10.1074/jbc.M706464200

Xu, L., Eu, J. P., Meissner, G., and Stamler, J. S. (1998). Activation of the cardiac calcium release channel (ryanodine receptor) by poly-S-nitrosylation. Science 279, 234-237. doi: 10.1126/science.279.5348.234

Xue, Y., Liu, Z., Gao, X., Jin, C., Wen, L., Yao, X., et al. (2010). GPS-SNO: computational prediction of protein S-nitrosylation sites with a modified GPS algorithm. PLoS ONE 5:e11290. doi: 10.1371/journal.pone.0011290

Yeh, D. C., Duncan, J. A., Yamashita, S., and Michel, T. (1999). Depalmitoylation of endothelial nitric-oxide synthase by acyl-protein thioesterase 1 is potentiated by $\mathrm{Ca}(2+)$-calmodulin. J. Biol. Chem. 274, 33148-33154. doi: 10.1074/jbc.274.46.33148

Zhang, C., Hein, T. W., Wang, W., Chang, C. I., and Kuo, L. (2001). Constitutive expression of arginase in microvascular endothelial cells counteracts nitric oxide-mediated vasodilatory function. FASEB J. 15, 1264-1266. doi: 10.1096/fj.00-0681fje

Zhang, C., Hein, T. W., Wang, W., Miller, M. W., Fossum, T. W., McDonald, M. M., et al. (2004). Upregulation of vascular arginase in hypertension decreases nitric oxide-mediated dilation of coronary arterioles. Hypertension 44, 935-943. doi: 10.1161/01.HYP.0000146907.82869.f2

Zhang, Q., Church, J. E., Jagnandan, D., Catravas, J. D., Sessa, W. C., and Fulton, D. (2006). Functional relevance of Golgi- and plasma membrane-localized endothelial NO synthase in reconstituted endothelial cells. Arterioscler. Thromb. Vasc. Biol. 26, 1015-1021. doi: 10.1161/01.ATV.0000216044.49494.c4
Ziche, M., and Morbidelli, L. (2000). Nitric oxide and angiogenesis. J. Neurooncol. 50, 139-148. doi: 10.1023/A:1006431309841

Ziche, M., Morbidelli, L., Masini, E., Granger, H., Geppetti, P., and Ledda, F. (1993). Nitric oxide promotes DNA synthesis and cyclic GMP formation in endothelial cells from postcapillary venules. Biochem. Biophys. Res. Commun. 192, 1198-1203. doi: 10.1006/bbrc.1993.1543

Zickus, M. A., Fonseca, F. V., Tummala, M., Black, S. M., and Ryzhov, V. (2008). Identification of the tyrosine nitration sites in human endothelial nitric oxide synthase by liquid chromatography-mass spectrometry. Eur. J. Mass Spectrom. 14, 239-247. doi: 10.1255/ejms.927

Ziegler, T., Silacci, P., Harrison, V. J., and Hayoz, D. (1998). Nitric oxide synthase expression in endothelial cells exposed to mechanical forces. Hypertension 32, 351-355. doi: 10.1161/01.HYP.32.2.351

Zimmermann, K., Opitz, N., Dedio, J., Renne, C., Muller-Esterl, W., and Oess, S. (2002). NOSTRIN: a protein modulating nitric oxide release and subcellular distribution of endothelial nitric oxide synthase. Proc. Natl. Acad. Sci. U.S.A. 99, 17167-17172. doi: 10.1073/pnas.252345399

Zimmet, J. M., and Hare, J. M. (2006). Nitroso-redox interactions in the cardiovascular system. Circulation 114, 1531-1544. doi: 10.1161/CIRCULATIONAHA.105.605519

Zou, M. H., Shi, C., and Cohen, R. A. (2002). Oxidation of the zinc-thiolate complex and uncoupling of endothelial nitric oxide synthase by peroxynitrite. J. Clin. Invest. 109, 817-826. doi: 10.1172/JCI14442

Conflict of Interest Statement: The authors declare that the research was conducted in the absence of any commercial or financial relationships that could be construed as a potential conflict of interest.

Received: 04 September 2013; accepted: 11 November 2013; published online: 13 December 2013.

Citation: Qian J and Fulton D (2013) Post-translational regulation of endothelial nitric oxide synthase in vascular endothelium. Front. Physiol. 4:347. doi: 10.3389/ fphys.2013.00347

This article was submitted to Oxidant Physiology, a section of the journal Frontiers in Physiology.

Copyright (๑) 2013 Qian and Fulton. This is an open-access article distributed under the terms of the Creative Commons Attribution License (CC BY). The use, distribution or reproduction in other forums is permitted, provided the original author(s) or licensor are credited and that the original publication in this journal is cited, in accordance with accepted academic practice. No use, distribution or reproduction is permitted which does not comply with these terms. 